\title{
Determination of Some Selected Thermal Properties of Pumpkin Seeds (Cucurbita pepo)
}

\section{*SUNMONU, MO; ${ }^{1}$ ODEWOLE, MM; ${ }^{2}$ ADEYINKA, OA; ${ }^{1}$ SANUSI, MS; ${ }^{4}$ MUSA, SO}

\author{
${ }^{* 1}$ Department of Food Engineering, University of Ilorin, Ilorin, Kwara State, Nigeria \\ ${ }^{2}$ Department of Agricultural and Biosystems Engineering, University of Ilorin, Ilorin, Kwara State, Nigeria \\ *Corresponding Author Email: sholams2000@yahoo.co.uk; odewole2005@yahoo.com; Other Authors Email: olabamiboade@gmail.com; \\ sanusimayowa@gmail.com; sulymanola11@gmail.com
}

\begin{abstract}
In this study, some selected thermal properties (specific heat, thermal conductivity and thermal diffusivity) in the moisture content range of $5.0-5.6 \%$ or green and $4.80-5.20 \%$ for white varieties of pumpkin seeds were determined. The specific heat was measured using mixture method while the thermal conductivity was measured by transient technique using the heat line source. The green pumpkin seed has average moisture content of 5.2\% higher than moisture content of white pumpkin seed of average $4.8 \%$. The average specific heat values of green pumpkin seed are $6.171 \mathrm{~kJ} / \mathrm{kgK}$ and white pumpkin seed $4.327 \mathrm{~kJ} / \mathrm{kgK}$. The thermal conductivity values for white pumpkin seed ranged from 0.074 to $0.288 \mathrm{~W} / \mathrm{m}^{\circ} \mathrm{C}$ while that for green pumpkin seed ranged from 0.079 to $0.433 \mathrm{~W} / \mathrm{m}^{\circ} \mathrm{C}$. The thermal diffusivity values for green pumpkin ranged from 0.0011 to $0.06 \mathrm{~m}^{2} / \mathrm{s}$ while that for white pumpkin seed ranged from 0.01 to 0.06 $\mathrm{m}^{2} / \mathrm{s}$. It was concluded that the higher the moisture content $(5.2 \%)$ the higher the value of specific heat of seed $(6.171 \mathrm{~kJ} / \mathrm{kgK})$. It can also be concluded that the thermal conductivity $\left(0.079\right.$ to $\left.0.433 \mathrm{~W} / \mathrm{m}^{\circ} \mathrm{C}\right)$ value is higher with high moisture content (5.2\%).
\end{abstract}

\section{DOI: $\underline{\text { https://dx.doi.org/10.4314/jasem.v25i4.17 }}$}

Copyright: Copyright $\left({ }^{\circ} 2021\right.$ Etuk et al. This is an open access article distributed under the Creative Commons Attribution License (CCL), which permits unrestricted use, distribution, and reproduction in any medium, provided the original work is properly cited.

Dates: Received: 14 February 2021; Revised: 26 March 2021; Accepted: 12 April 2021

Keywords: thermal, conductivity, transient, technique, diffusivity, pumpkin

The Knowledge of the thermal properties of agricultural materials is essential for modeling, optimization and design of practices and processing equipment for operations based on heat treatment, including dehydration, bleaching, cooking, heating, cooling, vaporizing and freezing (Alagusundaram et al., 1991).Thermal properties of foods are those properties that control the transfer and storage of heat in a particular food (Lozano, 2006). Thermal properties of most fruits and vegetables are significantly influenced by their moisture content and it is also affected by temperature, the chemical composition and physical structure of the fruits and vegetables. Besides processing and preservation, thermal properties also affect the sensory quality of foods as well as energy saving from processing. Knowledge of these properties is very necessary for modeling, simulation and optimization of process operations which involves heat transfer. Thermal conductivity, thermal diffusion, and specific heat capacity are the important three engineering properties of materials which affect heat transfer properties. These parameters are necessary for studies on heating, drying and cooling of food processes (Yang et al., 2002). The primary thermal properties of food and agricultural products are specific heat, thermal conductivity and thermal diffusivity. Specific heat is the property needed in the estimation of the amount of energy required to change the temperature of a product, while thermal conductivity and thermal diffusivity are involved in the determination of the rate of heat transfer for efficient process and equipment design (Wallapapan and Sweat, 1982).Cucurbita pepo is form the family Cucurbitaceae, is Cucurbita pepo, (Common name: Pumpkin; Yoruba: Elegede), a medium sized plant grown for its Fruits and edible seeds. Hence, it is known to be used as food and in herbal formulation in Nigeria. The ways of expanding the use of available local food sources are increasingly pursued, some of these local food sources contain

*Corresponding Author Email: sholams2000@yahoo.co.uk; odewole2005@yahoo.com 
seeds, many reports on some lesser known seeds and fruits indicated that they could be good sources of nutrients for both man and livestock (Elemo et al., 2002).Pumpkin has been cultivated for the more than 10,000 years in different locations of the world, (Idouraine et al., 1996); with records of its oil extraction in countries such as Austria, Slovenia and Hungary, (Murkovic et al., 1999). Pumpkins have been cultivated for nutritional and medicinal/pharmacological applications; some of the pharmacological effects include anti-diabetic, antihypertensive, antibacterial, antihypercholesterolemia, immunomodulation, intestinal anti-parasitic, antalgic and anti-imflamation effects have been reported, (Bannayanet al., 2011).Cucurbita pepo contain bioactive compounds which have antifatigue activity and can elevate exercise performance. The seeds were said to have bioactivities such as hepatoprotection, antidiabetes, anticancer, and anti-obesity properties (Wang, 2012).Pumpkin (Cucurbita pepo) seeds are a moderate to very good source of a variety of nutrients, including minerals, protein and healthy fats. Curcurbita pepo seeds are good sources of lipids and proteins (Achi, et al., 2005). Seeds oil pumpkins are a good raw material for the production of oil used in food preparation and in medicine (Lazos, 1986).Pumpkin (Cucurbita pepo) seeds are a moderate to very good source of a variety of nutrients, including minerals, protein and healthy fats. They provide a significant of dietary copper, zinc, iron and magnesium. Also, the seeds are used in nutrition in various forms and the seeds may be eaten whole. Cucurbita seeds are good sources of lipids and proteins (Achi et al., 2005).The seed (Pumpkin seed) contain oil and some nutrients and before the oil can be extract it has to undergo some processes which involve heat like drying, frying etc. The seed of Cucurbita pepo contains 30 to $51 \%$ of oil; other constituents are fatty acids-linoleic and oleic acids (27 to $38 \%$ ); proteins (31 to $51 \%$ ), carbohydrate (6 to $10 \%$ ); mineral elements (4 to 5\%). Thesitosterol constituent has been shown to be a strong inhibitor of prostaglandin biosynthesis in prostatic tissue of patients with Benign Prostatic Hyperplasia (BPH). Hence, its use as an alternative treatment for stages I and II BPH (Zdunczyk et al., 1999; Duke and Ayensu, 1985).There is need to determine the thermal properties of Pumpkin seed. (Cucurbita pepo) which would be very useful in the design and development construction of efficient processing and handling equipment and machines needed to harness the inherent qualities of the seed. This study therefore aimed at determining some selected thermal properties (Specific heat, Thermal conductivity and Thermal diffusivity) of two varieties (Green and White)of Pumpkin seed (Cucurbitapepo) relevant to the design and handling of food and agricultural equipment and machines.

\section{MATERIALS AND METHODS}

Selection of material: Fresh Pumpkin pods were bought from Kodi's market behind Mobil filling station Gegele road, Isale-oja, Ilorin West Local Government, Ilorin, Kwara state of Nigeria. The two varieties of Pumpkin used were Green and white pumpkin seeds (Cucurbita pepo).

Material preparation: The pod of the materials were removed by the used of cutlass to reveal the seed. Then the seed were dried by air drying after they were well dried, the seeds were shelled. The seeds were cleaned and sorted to remove all foreign material by hand picking.

Determination of moisture content: The moisture content of Pumpkin seed (Cucurbitapepo) was determine in the Faculty of Agriculture Laboratory, University of Ilorin. Using oven drying method. The Oven of E53 type with model no 89083.

$$
M C=\frac{M_{1-M_{2}}}{M_{1}} \times 100(w \cdot b)(1)
$$

Where $\mathrm{MC} ; \mathrm{M}_{1}$ is the weight of sample before drying; $\mathrm{M}_{2}$ is the weight of sample after drying

Determination of specific heat of pumpkin seeds: Specific heat of two varieties of (White and Green) Pumpkin seed (Cucurbita pepo) were determined in Agricultural and Biosystems Engineering Laboratory, University of Ilorin using the method of mixtures (Mohsenin, 1980).

$$
\mathrm{M}_{\mathrm{S}} \mathrm{C}_{\mathrm{S}} \mathrm{Q}_{\mathrm{S}}=\mathrm{M}_{\mathrm{C}} \mathrm{C}_{\mathrm{C}} \Delta \mathrm{T}+\mathrm{M}_{\mathrm{W}} \mathrm{C}_{\mathrm{W}} \Delta \mathrm{T}
$$

Where $\mathrm{M}_{S} \mathrm{C}_{S} \mathrm{Q}_{\mathrm{s}}=$ Heat lost by the seeds; $\mathrm{M}_{\mathrm{C}} \mathrm{C}_{\mathrm{C}} \Delta \mathrm{T}=$ Heat gained by the calorimeter and $\mathrm{M}_{\mathrm{W}} \mathrm{C}_{\mathrm{W}} \Delta \mathrm{T}=$ Heat gained by the water 


$$
C_{S=} \frac{\left(M_{C} x C_{C} x \Delta T\right)+\left(M_{W} x C_{W} x \Delta T\right)}{M_{C} Q_{S}}
$$

Where: $\mathrm{M}_{\mathrm{c}}$ is the mass of calorimeter and $\mathrm{C}_{\mathrm{c}}$ is the specific heat of calorimeter; $\Delta \mathrm{T}$ is temperature difference, $M_{W}$ is the mass of water; $C_{W}$ is the specific heat capacity of water; $\mathrm{C}_{S}$ is the specific heat capacity of the seed and $\mathrm{Q}_{\mathrm{s}}$ is temperature of the seed

Determination of thermal conductivity of pumpkin seed: Thermal conductivity values of the two varieties (Green and White) Pumpkin seed were determined by transient heat flow using line- heat source principle. Thermal conductivity was measured by the transient technique using the line heat source method assembled in a thermal conductivity probe. From the result obtained from the experiment, the temperature values and the elapsed time. The thermal conductivity was calculated using this relationship:

$$
k=\frac{Q}{4 \pi\left(T_{2}-T_{1}\right)} \ln \frac{t_{2}}{t_{1}}
$$

Where: $\mathrm{k}$ is thermal conductivity of the sample $(\mathrm{W} / \mathrm{mK})$; Q power dissipation by heat wire $(\mathrm{W} / \mathrm{m}) ; \mathrm{T}_{1}$ is the temperature of the probe thermocouple at initial time $\mathrm{t}_{1}\left({ }^{\circ} \mathrm{C}\right) ; \mathrm{T}_{2}$ is the temperature of the probe thermocouple at final time $\mathrm{t}_{2}\left({ }^{\circ} \mathrm{C}\right) ; \mathrm{t}_{1}$ andt $_{2}$ is the time since probe heater energized (s)

Determination of bulk density of pumpkin seed: The bulk density of two varieties of Pumpkin seeds was determined in Agricultural and Biosystems Engineering Laboratory, University of Ilorin. The height and diameter of the Tin Can used was first measured using Vernier caliper, both height and diameter were used for calculation of volume of the Can. The Can was weighed with Electric weighing balance and filled the ground Pumpkin seed, the seed was given blow (i.e compaction) and place gently on the Electric weighing balance and weight reading was recorded. The equation used for calculate bulk density was given as:

$$
B \cdot D=\frac{M}{V}
$$

Where: B.D is bulk density $\left(\mathrm{g} / \mathrm{cm}^{3}\right), M$ is mass of pumpkin seed $(\mathrm{g})$ and $\mathrm{V}$ is volume of the Tin Can $\left(\mathrm{cm}^{3}\right)$
Determination of thermal diffusivity of pumpkin seed: The thermal diffusivity of Pumpkin seed was calculated from experimentally determined values of thermal conductivity, specific heat and bulk density using this equation:

$$
\alpha=\frac{k}{\rho C_{p}}
$$

Where: ais the thermal diffusivity $\left(\mathrm{m}^{2} / \mathrm{s}\right) ; \mathrm{K}$ is the thermal conductivity $(\mathrm{W} / \mathrm{mK}) ; \rho$ is the bulk density $\left(\mathrm{kg} / \mathrm{m}^{3}\right) ; \mathrm{C}_{\mathrm{p}}$ is the specific heat capacity $(\mathrm{kJ} / \mathrm{kg} / \mathrm{k})$

\section{RESULTS AND DISCUSSION}

The thermal properties for the two varieties of pumpkin seeds (white and green) are shown in Table 1.Thermal diffusivity seems to be negligibly higher in white than in green pumpkin seed. While thermal conductivity was appear to be substantially higher in green pumpkin seed than in white pumpkin seed. Similarly, the specific heat of green pumpkin seed was significantly higher also appear to be substantially higher in green pumpkin seed than in white pumpkin seed.

The conclusion here is that, the observed differences the properties between the two seed variety are suggestive of the fact that green pumpkin might have higher conductivity, and higher specific compared to white pumpkin seed given that all other external factors outside this control are held constant.

Testing for Equality of Thermal Conductivity, Diffusivity and Specific Heat of the two Seed Variety: Although there were deviations of the data above from their respective mean, it was attempted to test whether or not these deviations are mere random occurrence. Here, the interesting properties are Specific heat of seed $\mathrm{Cs}(\mathrm{kJ} / \mathrm{kgK})$, thermal diffusivity $(\alpha)$ and thermal conductivity $(\mathrm{K})$.

The result on Table 4.2 shows that thermal conductivity and Specific heat of seed Cs $(\mathrm{kJ} / \mathrm{kgK})$ were statistically higher in green pumpkin seed than in white pumpkin seed. This support the earlier findings that thermal conductivity and specific heat of green pumpkin seed were substantially (significantly) higher than those of white pumpkin seed. 
Table 1 Descriptive statistics of the measured parameters

\begin{tabular}{llllll}
\hline Properties & Seed Type & Mean & Std. Dev & Minimum & Maximum \\
\hline Spec. heat of calor. & Green Pumpkin seed & 0.500 & 0.000 & 0.500 & 0.500 \\
$\mathrm{CC}(\mathrm{kJ} / \mathrm{kgK})$ & White pumpkin seed & 0.500 & 0.000 & 0.500 & 0.500 \\
\hline Temp. difference & Green Pumpkin seed & 4.333 & 0.289 & 4.000 & 4.500 \\
$\Delta \mathrm{T}(\mathrm{K})$ & White pumpkin seed & 3.167 & 0.289 & 3.000 & 3.500 \\
\hline Mass of seed MS & Green Pumpkin seed & 0.004 & 0.000 & 0.004 & 0.004 \\
$(\mathrm{~kg})$ & White pumpkin seed & 0.004 & 0.000 & 0.004 & 0.004 \\
\hline Temp. of seed QS & Green Pumpkin seed & 65.333 & 0.764 & 64.500 & 66.000 \\
$(\mathrm{~K})$ & White pumpkin seed & 67.000 & 0.500 & 66.500 & 67.500 \\
\hline Spec. heat of seed & Green Pumpkin seed & 6.171 & 0.189 & 6.021 & 6.384 \\
Cs $(\mathrm{kJ} / \mathrm{kgK})$ & White pumpkin seed & 4.327 & 0.424 & 4.067 & 4.816 \\
\hline Thermal diffusivity & Green Pumpkin seed & 0.0220 & 0.0122 & 0.0125 & 0.0650 \\
$(\alpha)$ & White pumpkin seed & 0.0233 & 0.0094 & 0.0119 & 0.0618 \\
\hline thermal & Green Pumpkin seed & 0.1464 & 0.0814 & 0.0830 & 0.4330 \\
conductivity $(\mathrm{K})$ & White pumpkin seed & 0.1095 & 0.0433 & 0.0750 & 0.2890 \\
\hline
\end{tabular}

Table 2 T-test for Equality of Means

\begin{tabular}{|c|c|c|c|c|c|c|c|}
\hline \multirow{2}{*}{ Parameters } & \multirow{2}{*}{$\mathrm{T}$} & \multirow{2}{*}{ Df } & \multirow{2}{*}{$\begin{array}{l}\text { Sig. (2- } \\
\text { tailed) }\end{array}$} & \multirow{2}{*}{$\begin{array}{l}\text { Mean } \\
\text { Difference }\end{array}$} & \multirow{2}{*}{$\begin{array}{l}\text { Std. Error } \\
\text { Difference }\end{array}$} & \multicolumn{2}{|l|}{$95 \% \mathrm{CI}$} \\
\hline & & & & & & Lower & Upper \\
\hline Thermal Cond. $\left(k, \mathrm{~W} / \mathrm{m}^{2} \mathrm{~K}\right)$ & 2.214 & 58 & 0.031 & 0.037 & 0.017 & 0.004 & 0.070 \\
\hline Thermal Diffu. $(\alpha)$ & -0.461 & 58 & 0.646 & -0.001 & 0.003 & -0.007 & 0.004 \\
\hline $\mathrm{SHS} c_{s}(\mathrm{~kJ} / \mathrm{kgK})$ & 6.880 & 4 & 0.002 & 1.845 & 0.268 & 1.100 & 2.589 \\
\hline
\end{tabular}

The thermal properties of two varieties of Pumpkin seed (Green and White Pumpkin seed) Cucurbita pepowere presented in Table 1 . The average moisture content of $5.2 \%$ was for green pumpkin seed and $4.8 \%$ for white pumpkin seed. The moisture content of the two varieties seeds were observed to determine the effect of moisture content on thermal properties. The variety of the seed with high moisture content (i.e Green pumpkin seed) has higher value of specific heat of $6.171 \mathrm{~kJ} / \mathrm{kgK}$, thermal conductivity range from 0.079 to $0.433 \mathrm{~W} / \mathrm{m}^{\circ} \mathrm{C}$ and thermal diffusivity from 0.0011 to $0.06 \mathrm{~m}^{2} / \mathrm{s}$ than the other variety (i.e White pumpkin seed) with specific heat of $4.327 \mathrm{~kJ} / \mathrm{kgK}$, thermal conductivity from 0.074 to $0.288 \mathrm{~W} / \mathrm{m}^{\circ} \mathrm{C}$ and thermal diffusivity from 0.01 to $0.06 \mathrm{~m}^{2} / \mathrm{s}$. This is in line with the findings from Pedro et al. (2013). He revealed that the thermal properties of Conilon coffee depend on the moisture content. The specific heat and thermal conductivity of fruits of Conilon coffee increases with increasing moisture content, whereas thermal diffusivity decreases with increasing moisture content (Pedro et al, 2013). The results from this research is also in line with the study by Bart-Plang et al., 2012a on thermal properties of GrosMichel banana grown in Ghana, the thermal conductivity coefficient of banana was reported to vary from $0.249 \mathrm{~W} / \mathrm{m} /{ }^{\circ} \mathrm{C}$ to $0.458 \mathrm{~W} / \mathrm{m}^{\circ} \mathrm{C}$, while thermal diffusivity coefficient varied from $1.15 \times 10-7 \mathrm{~m} 2 / \mathrm{s}$ to $1.62 \times 10-7 \mathrm{~m} 2 / \mathrm{s}$ and specific heat varied from $1574 \mathrm{~kJ} / \mathrm{kg} /{ }^{\circ} \mathrm{C}$ to 2506 $\mathrm{kJ} / \mathrm{kg} /{ }^{\circ} \mathrm{C}$. As a result, specific heat, thermal conductivity coefficient and thermal diffusivity coefficient increased with increase in the moisture content. The results obtained are in line with the results obtained from Yang et al.2002 and Verma et al. 2000.Thermal conductivity, specific heat, and thermal diffusivity of borage seeds were obtained by Yang et al.2002, they determined by increase in moisture from 1.2 to $30.3 \%$ (w.b.\%) thermal conductivity will increase from 0.11 to $0.28 \mathrm{~W} . \mathrm{m}^{-1}{ }^{\circ} \mathrm{K}^{-1}$ and specific heat will change from 0.77 to $1.99 \mathrm{~kJ}^{\mathrm{kg}}{ }^{-1} \mathrm{~K}^{-1}$ and thermal diffusivity will go from $2.32 \times 10^{-7}$ to $3.18 \times 10^{-7} \mathrm{~m}^{2} \mathrm{~S}^{-1}$. Verma and Prasad experiments on corn showed that when moisture go from $10 \%$ to $50 \%$ thermal conductivity, specific heat and thermal diffusivity increased from 0.125 to $0.193 \mathrm{Wm}^{-1}{ }^{\circ} \mathrm{C}^{-1}$ and from

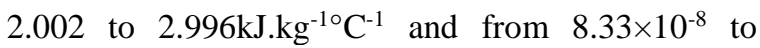
$10.17 \times 10^{-8} \mathrm{~m}^{2} \mathrm{~S}^{-1}$ respectively. Verma et al. 2000 studies on pod, seed and shell of peanut showed, specific heat changed from 2.1 to $3.3,1.9$ to 2.8 and 2.7 to $4.1 \mathrm{~kJ}^{\mathrm{kg}} \mathrm{kg}^{-1} \mathrm{C}^{-1}$ respectively, however moisture content increased from 5.2 to $23.7,5$ to 30.6 and 3.5 to $28.7 \%$ (d.b.). Thermal conductivity of pod, seed and shell increased from 0.12 to $0.16,0.15$ to 0.19 and 0.11 to $0.18 \mathrm{~W} \cdot \mathrm{m}^{-10} \mathrm{C}^{-1}$ respectively and by increase in moisture content. Thermal diffusivity of pod and seed in that moisture range reduced from $2.8 \times 10^{-8}$ to 
$2.3 \times 10^{-8}$ and $1.1 \times 10^{-8}$ to $1 \times 10^{-8} \mathrm{~m}^{2} \cdot \mathrm{S}^{-1}$ and thermal diffusivity of shell increased from $5.9 \times 10^{-8}$ to $6.7 \times 10^{-}$ ${ }^{8} \mathrm{~m}^{2} \mathrm{~S}^{-1}$ (Venkata, et al.2010). Researchers used mixture method to determine specific heat of peanut pod and reported that specific heat of pod increased by increase in moisture content and temperature (Suter et al. 1975).

Conclusions: This research focused on the determination of some selected thermal properties of Pumpkin seed (Cucurbita pepo) related to the design of food handling and processing machines. The thermal properties determined for both green and white Pumpkin seeds were specific heat, thermal conductivity and thermal diffusivity. It can be concluded that the determined engineering properties are vital for the design of postharvest handling and processing systems for almond seeds as statistical test showed that there are significant differences between the thermal properties of the two seeds studied.

\section{REFERENCES}

ACHI, M; FOKOU, E; TCHIEGANG, C; FOTSO, M; MBIAPO, F (2005). "Nutritive value of some cucurbutaceae oilseeds from different regions in Cameroon”.Afr. J. Bio-tech. 4 (11) 1334-1339

ALAGUSUNDARAM, K; JAYAS, DS; MUIR, WE; WHUTE NDG (1991). "Thermal Conductivity of bulk barley, lentils and peas. Transactions of the ASABE.34 (4) 1784-1788

BANNAYAN, M; REZAEI, E; ALIZADEH, A (2011). Climatic suitability of growing summer squash (Cucurbiataceaepeop L) as a medicinal plant in Iran.Notulae Scientia Bioloieae. 3 (2): 3946.

BART-PLANGE, AA; ADDO, FK; PIEGU, AK (2012). Some moisture dependent thermal properties of cashew kernel (Anarcardium occidentale L.).Australian J. Agric. Engineer. 3(2): 65-69.

DUKE, JA; AYENSU, ES. (1985). Medicinal Plants of China. Reference Publication Inc.

ELEMO, BO; ELEMO, GN; OLADIMEJI, OO; KOMOLAFE, YO (2002). Studies on the composition of some nutrients and anti-nutrients of sheanut (Butyrospemumparkii).Nig. Food J. 20: 69-73.

IDOURAINE, A; KOHLHEPP, EA; WEBER, CW (1996). Nutrient Constituents from Eight Lines of Naked Seed Squash (Cucurbita pepo). J. Agric. Food Chem. 44:721-724.

LAZOS, S (1986). "Nutritional, fatty acids and oil characteristics of pumpkin and melon seeds". $J$. Food Sci.15. 1382-1383

LOZANO, JE (2006). Thermal properties of food. Food Engineering. 1: 1-7

MOHSENIN, NN (1980). Thermal Properties of Foods and Agricultural Materials ( $2^{\text {nd }}$ Edition). New York: Gordon and Breach. Pp 100-104

MURKOVIC, M; HILLEBRAND, A; DRAXI, S; WINKLER, J; PFANNHAUSER, W (1999). Distribution of fatty acids and vitamin E contents in pumpkin seed (Cucurbitta pepo L.) in Breeding Lines. Acta Horti. 498:47-55.

PEDRO, C; PAULO, CC; KATTIA, S; JULIO, CC (2013).Thermal properties of conilon coffee fruits. J. Engineer. 3 (11) 29-35.

SUTER, DA; AGRAWAL, KK; CLARY, VI (1975). Thermal properties of peanut pods, hulls and kernels. Transactions of the ASAE. 18 (2). 370375

VERMA, BC; PRASAD, S (2000). Mechanical and thermal properties of maize. Journal of Food Sciences and Technology. 37 (5):500-505.

WALLANPAPAN, K; SWEAT, VE (1982). Thermal conductivity of defatted soy flour. Transactions of ASAE. 25 (5) 1440-1444.

WANG, SY (2012) "Pumpkin (Cucurbita moschata) fruit extract improves physical fatigue and exercise performance in mice". molecules (Basel, Switzerland).17 (10) 11864-76.

YANG, W; SOKHANSANJ, S; TANG, J; WINTER, $P$ (2002). Determination of thermal conductivity, 
specific heat and thermal diffusivity of borage seeds. Biosystems Engineering. 82 (2): 169-176.

ZDUNCZYK, Z; MINAKOWSKI, D; FREJNAGEL, S; FLIS, M (1999). Comparative study of the chemical composition and nutritional value of pumpkin seed cake, soybean meal and casein.Nahrung. 43: 392-395. 